\title{
REPRESENTASI BROMANCE DAN MASKULINITAS DALAM NOVEL UNTUK DIA YANG TERLAMBAT GUE TEMUKAN KARYA ESTI KINASIH
}

\section{BROMANCE REPRESENTATION AND MASCULINITY IN NOVEL UNTUK DIA YANG TERLAMBAT GUE TEMUKAN WRITTEN BY ESTI KINASIH}

\author{
Tania Intan ${ }^{1 *}$, Nany Ismail ${ }^{2}$ \\ Departemen Susastra dan Kajian Budaya, Universitas Padjadjaran, Indonesia ${ }^{1}$, \\ Departemen Linguistik, Universitas Padjadjaran, Indonesia ${ }^{2}$ \\ tania.intan@unpad.ac.id ${ }^{1}$, nany.ismail@unpad.ac.id ${ }^{2}$ \\ *penulis korespondensi
}

\begin{tabular}{ll}
\hline Info Artikel & ABSTRAK \\
\hline Sejarah artikel: & Bromance merupakan hubungan dekat dan relatif intim di antara dua laki- \\
Diterima: & laki atau lebih, tanpa didasari oleh ketertarikan seksual. Penelitian ini \\
20 Desember 2020 & membahas bromance dan maskulinitas yang direpresentasikan di dalam \\
Direvisi: & novel bergenre teen lit Untuk Dia yang Terlambat Gue Temukan (2020) \\
18 Juni 2021 & karya Esti Kinasih. Penelitian ini menggunakan metode deskriptif-kualitatif \\
Disetujui: & dengan pendekatan gender. Data berupa kata, frasa, dan kalimat \\
3 Juli 2021 & dikumpulkan dengan teknik simak catat setelah dilakukan pembacaan \\
& tertutup. Data kemudian diklasifikasi, diinterpretasi, dan dikaji dengan \\
Kata kunci: & teknik analisis isi. Hasil penelitian menunjukkan bahwa relasi bromance \\
bromance, Esti Kinasih, & dibangun di antara para tokoh laki-laki dengan latar sekolah dan konteks \\
maskulinitas, teen lit & permasalahan remaja. Alasan yang mendasari bromance adalah kesamaan \\
& kepentingan dan pemahaman sebagai sesama laki-laki. Manifestasi \\
& bromance ditunjukkan melalui sikap mendengarkan, memahami, \\
& membantu, dan melindungi. Relasi bromance kuat karena laki-laki bekerja \\
& sama untuk tidak tampil sebagai pihak yang lemah dan emosional (terutama) \\
& di hadapan perempuan. Perempuan sendiri ditampilkan pasif, lemah, dan \\
& patuh menghadapi laki-laki dan persekutuan mereka di dalam bromance.
\end{tabular}

\begin{tabular}{ll}
\hline Article Info & ABSTRACT \\
\hline $\begin{array}{l}\text { Article history: } \\
\text { Received: }\end{array}$ & $\begin{array}{l}\text { Bromance is a close and relatively intimate relationship between two or } \\
\text { more men, without being based on sexual attraction. This research is aimed }\end{array}$ \\
$\begin{array}{l}\text { 20 December 2020 } \\
\text { Revised: }\end{array}$ & $\begin{array}{l}\text { at discussing the bromance and masculinity which is represented in the teen } \\
\text { literature genre in novel Untuk Dia yang Terlambat Gue Temukan }(2020)\end{array}$ \\
Accepted: & written by Esti Kinasih. This research uses descriptive-qualitative method \\
3 July 2021 & with a gender approach. Data in the form of words, phrases, and sentences \\
& were collected using a note-taking technique after a closed reading. The data \\
Keyword: & are then classified, interpreted, and reviewed using content analysis \\
Bromance,Esti & techniques. The results of this study indicate that Bromance relationships \\
Kinasih, & are built between male figures with school backgrounds and the context of \\
masculinity, teen & adolescent problems. The reason that underlies bromance is the same \\
literature & interests and understanding as fellow men. Bromance is manifested in an \\
attitude of listening, understanding, helping, and protecting. Bromance & relationships are strong because men work together to avoid appearing as \\
weak and emotional (especially) in front of women. Women themselves are \\
shown to be passive, weak, and obedient to men and their fellowship in \\
bromance.
\end{tabular}




\section{PENDAHULUAN}

Esti Kinasih adalah salah satu penulis perempuan yang produktif berkarya pada genre teen lit. Penulis kelahiran Jakarta, 9 September 1971 ini terpilih sebagai pengarang terfavorit pada tahun 2000-an (Rahmaningsih, 2014). Esti Kinasih menerbitkan novel pertamanya, Fairish, pada tahun 2004 yang kemudian dicetak sebanyak ke-10 kali dan telah diangkat ke layar sinetron. Novel-novelnya yang lain pun, seperti Cewek!!! (2005), Still (2006), Dia Tanpa Aku (2008), Jingga dan Senja (2010), Jingga dalam Elegi (2011), dan Jingga untuk Matahari (2017), mengikuti kesuksesan Fairish. Hampir seluruh karyanya tersebut menjadi best-sellers dengan angka penjualan mencapai lebih dari 60.000 eksemplar dan dicetak hingga belasan kali (Agnes, 2016).

Fanatisme penggemar karya-karya Esti Kinasih diwadahi oleh komunitas 'Estikinatic' yang didirikan pada tahun 2011. Melalui media sosial Instagram dan Twitter, mereka secara aktif membahas dan rutin mempromosikan novel-novel sang penulis favorit. Alasan para pembaca menyukai karyakarya penulis tersebut, menurut Kresnawati, adalah "ceritanya selalu seru dan manis" (Agnes, 2016). Tulisan Esti Kinasih juga dinilai mengasyikkan, khas remaja, dan tidak berkesan menggurui. Hal ini memperkuat gagasan Adji (2017), bahwa sastra populer memang sangat lekat dengan kehidupan anak muda, karena sastra populer mampu merekam dengan cermat setiap problematika aktual yang terus berkembang.

Meski kerap mendapat penilaian lebih rendah dari karya sastra serius atau kanonik, menurut Faruk (2012), karya sastra populer (seperti teen lit, chick lit, metropop, dan subgenre romance lainnya) dapat dikaji secara ilmiah karena merupakan produk budaya. Hal ini dijelaskan Faruk yang mengungkapkan bahwa kajian budaya menempatkan karya sastra populer sebagai objek kajian yang sama berharganya dengan karya sastra yang dianggap serius. Argumentasi tersebut didukung oleh kajian Noor (2017) yang menguraikan bagaimana sastra populer merupakan objek material penelitian sastra yang potensial karena sangat kaya akan bahan dan data. Penelitian terhadap karya sastra populer juga hendaknya tidak hanya melalui analisis struktur melainkan dikaitkan dengan wilayah keilmuaan lainnya.

Novel Untuk Dia yang Terlambat Gue Temukan (2020) yang selanjutnya diacu sebagai Untuk Dia, merupakan karya terbaru Esti Kinasih yang terbit pada tanggal 14 Oktober 2020. Novel tersebut dipilih sebagai objek formal kajian ini karena merupakan karya kontemporer dan terbaru dari pengarang tersebut, dan dalam penelusuran peneliti, belum ditemukan kajian terdahulu yang mengupasnya.

Novel Untuk Dia berpusat pada hubungan cinta segitiga di antara tokoh Roni, Rara, dan Rian. Kisah dinarasikan oleh pencerita dari luar yang bersifat mahatahu. Judul novel Untuk Dia yang Terlambat Gue Temukan merujuk pada ujaran tokoh Rian (Gue) yang merasa menyesal baru bertemu dengan Rara (Dia) saat dirinya duduk di kelas tiga dan akan pindah ke Sulawesi untuk jangka waktu yang lama.

Permasalahan jarak menjadi penting dan tampak sulit diatasi karena novel ini menggunakan latar waktu sekitar tahun 1980-1990 di mana teknologi komunikasi dan internet belum secanggih saat ini. Pergaulan anak SMA di kota Jakarta menjadi 
rasionalisasi dari penggunaan gaya bahasa sepanjang cerita yang cenderung informal dengan sapaan antarteman "lo-gue". Penggunaan ikonikon dan jenama dari tahun 80-90an mulai dari artis (Ira dan Ari Wibowo, Rano Karno, ...), pemusik dan lagunya (Motley Crue, Bon Jovi, Metallica, Megadeth, ...), tempat-tempat (Aldiron Plaza, Blok M, ...), makanan favorit anak muda (American Hamburger, Baso Blok S, Wendy's,...), serta baju (Osella, CF, dan Hammer) merupakan penanda nyata dari masa itu.

Benda-benda khas tahun 80-90 juga dimunculkan di dalam novel Untuk Dia, di antaranya adalah walkman (alat pemutar kaset), tipe-ex yang dilengkapi thinner, wadah gulungan film sebagai tempat menyimpan koin, serta telepon umum. Hiburan remaja pada masa itu juga ditampilkan Esti Kinasih, misalnya melalui hobi merekam lagu dari kaset asli ke kaset kosong. Hal tersebut dilakukan Rian maupun Roni yang merekam lagu-lagu cinta untuk diserahkan pada sosok perempuan yang disukai, yaitu Rara yang sedang berulang tahun.

Karakter hubungan percintaan pun disesuaikan dengan situasi remaja tahun delapan puluhan yang umumnya diungkapkan dengan cara malu-malu dan tidak terbuka. Media yang akrab digunakan remaja dalam proses menyatakan cinta saat itu, yaitu telepon umum dengan tumpukan koin atau melalui surat darurat berupa sobekan kertas buku tulis.

Tokoh utama dalam novel Untuk Dia terdiri dari Rara dan Roni yang duduk di kelas 2 Fis 2, sedangkan Rian adalah kakak kelas mereka di 3 Fis 3. Baik Roni maupun Rian diperlihatkan berusaha dengan berbagai cara untuk mendekati Rara.
Para tokoh digambarkan secara stereotipik gender. Sebagai perempuan, Rara ditampilkan malu-malu, pasif, dan menunggu saat mengetahui ada lakilaki yang menyukainya. Ia tidak sangat cantik, namun diperlihatkan sebagai sosok gadis manis yang menarik dan menyenangkan dengan mata yang bulat dan pipi 'tembem'.

Sebagai laki-laki, Roni digambarkan tampan dan bertubuh tinggi tegap. Ia cukup agresif dengan menunjukkan sinyal-sinyal perasaannya pada Rara melalui gestur dan simbol (mencari tahu bila Rara sudah punya pacar/ belum, memberinya apel yang dibagi dua, mengajak makan berdua, dan juga meneduhi tubuh perempuan itu saat upacara). Sebagai catatan, tindakan menghalangi sinar matahari dengan tubuh sendiri demi meneduhi tokoh perempuan juga digunakan oleh tokoh Ari terhadap Tari di dalam Jingga dan Senja (2010). Sementara itu, Rian ditampilkan lebih cerdas, agresif, dan terbuka dalam mengungkapkan rasa sukanya. Ia berkaca mata dan bertubuh lebih pendek dibandingkan Roni.

Sebagaimana di dalam karya-karya Esti Kinasih sebelumnya, latar yang digunakan dalam novel Untuk Dia juga adalah sekolah. Nama sekolah yang dimaksud adalah SMA Palagan, yang juga namanya digunakan dalam novel Fairish (2004).

Tema percintaan dan persahabatan dalam wilayah sekolah memang selalu menjadi permasalahan yang ditampilkan di dalam novel teen lit, termasuk karya-karya Esti Kinasih. Oleh karena itu, penelitian ini tidak akan berfokus pada permasalahan relasi cinta di antara para tokoh dalam novel tersebut, melainkan pada bromance yang dianggap akan lebih menarik untuk dipelajari. 
Bromance terbentuk dari kata bro 'saudara/teman laki-laki' dan romance 'romantis', yang menurut Wolfe (2016), berarti hubungan dekat di antara dua laki-laki heteroseksual (atau lebih), dengan emosi namun tanpa kedekatan seksual. Menurut Rinesti (2016), meskipun mengandung unsur kata romance 'percintaan', bromance tidak melibatkan cinta romantis di antara pelakunya.

Kata bromance disebut telah digunakan pada tahun 1960 (Maharrani, 2017). Namun, kajian DeAngelis menyatakan bahwa kata tersebut pertama kali dimunculkan oleh editor majalah Skateboard, David Carnie, pada tahun 1990-an. Kata tersebut baru sering muncul setelah film The 40-Year-Old Virgin yang dirilis tahun 2005 (Kirnandita, 2017). Fenomena bromance didukung oleh kecenderungan laki-laki masa kini yang menunda pernikahan sehingga mereka mendefinisi ulang arti pertemanan. Laki-laki pun kerap menghabiskan waktu dengan sahabat karib yang meningkatkan kualitas pertemuan dan keintiman mereka.

Teman bagi laki-laki diperlukan untuk berbagi rahasia terdalam. Dalam realita, bromance misalnya diilustrasikan oleh persahabatan di antara Barack Obama dengan Joe Biden, atau Blake Shelton dan Adam Levine pada acara The Voice US, sedangkan dalam fiksi seperti kedekatan di antara Batman dan Robin, atau Sherlock Holmes dengan Dr. Watson. Budaya populer juga memegang andil besar dalam membentuk persepsi dunia tentang bromance melalui konsteks situasi yang bervariasi, seperti 'rekan serumah' yang ditunjukkan tokoh Joey dan Chandler dalam serial Friends, atau Felix dan Oscar dalam The Odd
Couple. Keberadaan konsep bromance ini berkontribusi dalam mematahkan stereotip miring tentang pertemanan di antara laki-laki.

Seperti perempuan, laki-laki juga membutuhkan pertemanan di luar pernikahan atau hubungan cinta. Yang berbeda, laki-laki menggunakan lebih sedikit kata-kata, lebih tidak emosional, lebih sedikit berkontak fisik atau menunjukkan intimasi (Kirnandita, 2017). Menurut Moore, seorang psikoterapis dan konselor hubungan, dari temanlah laki-laki akan mendapatkan dukungan dan pengakuan (Kriswanti, 2019). Sejumlah laki-laki yang menjalin bromance, dalam penelitian yang dikutip Anwar (2017), mendeskripsikan hubungannya dengan laki-laki lain sebagai hubungan keluarga.

Dengan berlandaskan rasa percaya, mereka akan saling berbagi rahasia termasuk tentang masalah percintaan. Untuk membangun relasi bromance, selain ada ketertarikan pada hal yang sama, laki-laki yang bersahabat dekat itu juga harus memiliki perilaku serupa. Imelda (2017) mengutip kajian Kimmel, bahwa bromance dianggap lebih memberi kepuasan batin pada laki-laki dibandingkan dengan hubungan asmaranya dengan perempuan.

Menurut White, yang dijelaskan oleh Kirnandita (2017), perbedaan di antara relasi romantis dan bromance adalah lebih sedikitnya situasi penghakiman dan batasan dalam berdiskusi atau mengungkapkan emosi. Laki-laki dianggap dapat menyimpan rahasia dan sisi gelap temannya. Orang yang menyatakan rahasia pun tidak merasa akan dihakimi, diolok-olok, atau dianggap berbeda. Selain itu, lakilaki juga dinilai lebih pemaaf (Maharrani, 2017). Sebagaimana 
dinyatakan Sullivan yang dijelaskan oleh (Rinesti, 2016), cinta romantis mensyaratkan kontrol pada yang lain, sementara cinta dalam persahabatan justru memberi ruang bagi kedua belah pihak untuk tetap memegang kendali.

Dalam konteks psikologis, manusia, baik laki-laki maupun perempuan, tidak dapat terlepas dari manusia lain. Menurut Bergsma, Poot, dan Liefbroer, relasi interpersonal dapat memberikan bantuan, dukungan, dan kenyamanan, sehingga menjalin relasi menjadi sesuatu yang berharga bagi setiap individu (Febrieta, 2016). Dalam kajian Cavanaugh dan Blanchard-Fields (2006), dijelaskan perbedaan karakteristik persahabatan di antara perempuan dan laki-laki. Persahabatan perempuan cenderung mendiskusikan masalah personal, saling berbagi perasaan, memberi dan menerima dukungan emosional berupa saran. Sementara itu, persahabatan lakilaki menyukai pembicaraan tentang solusi permasalahan dan aktivitas.

Persahabatan di antara laki-laki memang bukan hal yang baru, namun sejak dulu kerap mendapat sorotan buruk karena tingginya ketakutan masyarakat pada fenomena homoseksual (homophobic). dalam kedekatan antarlaki-laki, mereka dibatasi oleh aturan seperti tidak boleh berpegangan tangan atau saling berpelukan (Hanani, 2019). Namun, pertemanan yang 'murni' dan produktif di antara laki-laki terutama dari kalangan figur publik pada berbagai media massa membuat bromance berangsur-angsur mendapat pandangan positif dan berterima.

Hubungan bromance dinilai unik karena bentuk kedekatan yang ditunjukkan tidak selalu 'normal', melainkan kerap berupa keusilan, pertukaran umpatan, dan tindakan bodoh atau kekanak-kanakan. Namun, di balik semua itu, masing-masing akan selalu ada untuk yang lain, menjadi tumpuan di saat sulit, dan memberi dukungan secara loyal hingga mengorbankan nyawa (Rinesti, 2016).

Dalam tulisan Imelda (2017) juga terungkap bahwa menurut laki-laki, memiliki teman dapat mengisi kekosongan emosional pada mereka yang tidak didapatkan dari pasangannya. Hal ini mengindikasikan bahwa bromance berpotensi membawa dampak baik pada laki-laki, namun signifikan mencemaskan bagi perempuan. Dalam relasi bromance, perempuan dibincangkan secara negatif, dianggap pendendam, dan tidak dapat diprediksi secara emosional (Maharrani, 2017).

Kedekatan di antara laki-laki menjadi sorotan, karena mereka telah dikonstruksi secara sosial sebagai mahluk maskulin yang kuat, rasional, soliter, dan serbabisa. Ketergantungan pada individu lain dan ekspresi emosi maupun rasa sakit akan dianggap sebagai kelemahan dan feminin (Rinesti, 2016). Padahal, di masa lalu, laki-laki telah biasa bersekutu dan bekerja sama untuk melakukan perburuan (Setiaji, 2020). Karena konstruksi budaya patriarki tersebut, laki-laki dituntut untuk selalu terlihat tanpa kelemahan, terlebih di hadapan perempuan. Nilai maskulin yang dominan ini dianggap mengekang dan tidak menguntungkan dalam beberapa aspek, tidak hanya oleh perempuan tapi juga oleh laki-laki sendiri (Hanani, 2019).

Secara akademis, kajian komprehensif tentang bromance telah dilakukan oleh Robinson dkk. (2017a; 2017b), Brook (2015), Oh (2018), Tait (2016), dan Thomson (2015). Tait (2016), dalam kajiannya terhadap film 
bromance berjudul Step Brothers, mengutip Kimmel, dan menyatakan bahwa: "Manhood is not the manifestation of an inner essence; it's socially constructed. Manhood does not bubble up to consciousness from our biological constitution; it is created in our culture."

Selain melalui kajian kuantitatif, Robinson (2017b) menyatakan bahwa pembahasan bromance telah cukup banyak ditelaah melalui representasinya di dalam dunia film dan televisi. Di dalam negeri, penelitian tentang film bromance telah dilakukan di antaranya oleh Hanani dan Reza (2019) yang mengkaji bromance di dalam film berlatar budaya Jawa Yowis Ben dengan teori semiotika Roland Barthes. Kajian tersebut menemukan bahwa dalam film tersebut, hubungan di antara para tokoh remaja laki-laki digambarkan memiliki kedekatan emosional maupun fisik. Namun, kedekatan tersebut tidak bersangkutan dengan perilaku homoseksual. Kurniawan dkk. (2020) mengerjakan pembuatan film pendek berjudul How Bromance Us dengan tema persahabatan non seksual di antara remaja laki-laki dengan pesan moral bahwa hubungan yang tulus mungkin saja dijalin di antara orang-orang yang saling memahami dan saling menghargai.

Pengkajian bromance di dalam novel sejauh ini belum ditemukan oleh peneliti, sebagaimana juga analisis terhadap novel Untuk Dia, karena karya tersebut relatif baru diterbitkan. Pembahasan terhadap novel-novel Esti Kinasih sendiri telah cukup banyak dilakukan, seperti oleh Putri (2020), Jumail (2019), Intan (2019), Pachrunisah (2017), dan Widjayanti (2016). Untuk membatasi bidang kajian, maka tujuan yang dirumuskan untuk penelitian ini adalah untuk membahas representasi bromance di dalam novel Untuk Dia karya Esti Kinasih.

\section{METODE}

Metode yang digunakan dalam penelitian ini adalah deskriptif kualitatif. Pendekatan yang digunakan adalah kajian gender, dengan pertimbangan bahwa bromance berkelindan dengan permasalahan maskulinitas.

Konsep gender digunakan untuk mengidentifikasi sifat yang dilekatkan pada laki-laki. Gender mengacu pada bagaimana laki-laki dan perempuan berperan dalam hidupnya. Bila perempuan dianggap memiliki karakter yang lemah lembut, penyayang, dan emosional, maka laki-laki dikonstruksi sebagai pihak yang kuat, mandiri, dan rasional. Padahal, menurut Priyatna (2018), gender bersifat fluid, artinya dapat berubah-ubah dan perannya dapat dipertukarkan, karena gender dikonstruksi oleh budaya.

Dengan mengambil sudut pandang perempuan, Beauvoir (2016) menjelaskan bahwa seseorang tidak 'dilahirkan' melainkan 'menjadi' perempuan. hal ini berarti bahwa sifat gender tidak datang secara otomatis sebagai 'kodrat' melainkan dilekatkan oleh masyarakat pada identitas individu tersebut. Beauvoir juga mengargumentasikan bahwa sejak kecil, perempuan dan laki-laki diajarkan hal-hal yang berbeda untuk menjadi seseorang. Perempuan belajar menjadi pasif dan peduli pada penampilannya sedangkan laki-laki belajar untuk menjadi aktif dan dominan.

Pendekatan gender berpijak pada konsep maskulinitas yang diusung Connell (2005) yang menyatakan 
bahwa maskulinitas tidak dapat dibentuk tanpa adanya femininitas. Maskulinitas, menurut Mosse, dipahami sebagai cara laki-laki menegaskan apa yang mereka yakini sebagai kejantanan mereka. Maskulinitas ideal tidak hanya merupakan simbol regenerasi pribadi melainkan juga sebagai dasar definisi diri dalam masyarakat modern (Permata, 2016). Laki-laki dikonstruksi sebagai pihak yang harus memiliki sifat tegas, agresif, teguh pendirian rasional, dan lebih baik daripada perempuan dalam mengendalikan emosi (Tong, 2010). Dengan demikian, jika individu yang ditandai sebagai laki-laki namun memiliki perilaku berbeda dengan gambaran tersebut ia dapat dianggap tidak normal.

Penelitian ini dilakukan dengan tahap-tahap sebagai berikut: data dikumpulkan dengan teknik simakcatat setelah peneliti melakukan pembacaan tertutup terhadap novel. Data kemudian diklasifikasi, diinterpretasi, dan dianalisis dengan menggunakan teori-teori yang relevan. Hasil analisis kemudian dirumuskan dalam bentuk simpulan.

Data diambil dari objek penelitian berupa novel bergenre teen lit dengan judul Untuk Dia Yang Terlambat Gue Temukan (2020) karya Esti Kinasih. Novel ini diterbitkan oleh PT. Gramedia Pustaka Utama.

\section{HASIL DAN PEMBAHASAN}

Untuk mendapatkan pemahaman yang utuh mengenai permasalahan yang dibicarakan di dalam novel Untuk Dia, maka pembahasan ini terbagi atas dua bagian, yaitu (1) manifestasi relasi bromance serta (2) kompleksitas bromance dan maskulinitas.

\section{Manifestasi Relasi Bromance dalam Novel Untuk Dia}

Bromance atau persahabatan di antara laki-laki dapat terbentuk karena ada timbal balik, saling percaya, kasih sayang, keterbukaan, dan perilaku suportif (Davies, 2016). Dalam novel Untuk Dia, bromance dijalin di antara beberapa tokoh dengan alasan dan manifestasi yang beragam. Hubungan persahabatan di antara Miko dan Rian merupakan representasi bromance yang paling jelas terlihat. Miko merupakan teman sebangku sekaligus sahabat karib Rian yang sangat dekat, dan menjadi tempat mencurahkan perasaannya tentang Rara, perempuan yang ia sukai.

Pagi-pagi Miko nemu pemandangan ganjil. Rian duduk termenung di bangkunya. Nggak ngapa-ngapain. Duduk aja. Bengong ngelihatin papan tulis, sementara kelas masih sepi.

Miko duduk di bangkunya pelanpelan, tanpa bunyi. Tas dia taruh di bawah, di lantai antara bangkunya dan bangku Rian, juga pelan-pelan.

Takut ganggu Rian yang lagi serius ngelamun. (Kinasih, 2020: 45)

Sebagai sahabat, Miko dapat memahami kondisi Rian yang sedang jatuh cinta pada Rara, yang ditunjukkan dengan frasa-frasa "langsung paham" (hlm. 36), "tersenyum" (hlm. 42), "tepuk-tepuk bahu teman sebangkunya itu" (hlm. 45). Situasi ini menunjukkan bagaimana gestur dan perkataan maupun sikap diam Miko menghadapi Rian yang sedang resah juga dapat ditangkap oleh tokoh-tokoh lainnya.

Yang bikin Rara terdiam adalah cara Miko tersenyum, 
menguatkan apa yang sempat disaksikan Rara dalam waktu yang amat singkat. Sampai Rara nggak yakin dia memang melihatnya. (Kinasih, 2020: 42)

Miko juga tidak banyak bertanya atau menghakimi Rian yang kerap bersikap aneh. Miko seperti selalu memahami apa alasan di balik perilaku temannya itu. Lebih jauh lagi, ia seperti mengetahui hal yang tidak diketahui siapa pun tentang Rian. Hal ini sesuai dengan teori Aiken bahwa laki-laki pada umumnya tidak suka menceritakan perasaan yang sedang dialaminya, namun ia mengharapkan dukungan dari sahabatnya.

Akhirnya Miko buka suara. " Ke kantin aja yuk. Makan gorengan, kali aja udah ada yang mateng. Gorengan tuh enak banget kalo masih anget. [...]." Rian sama sekali nggak pengin makan gorengan pagi-pagi. Bodo amat tuh gorengan masih anget. Dia pilih merana mengasihani diri di kelas.

Tapi Miko dan Irwan mencekal lengan Rian di kiri-kanan, lalu menyeretnya dengan paksa ke kantin. (Kinasih, 2020: 47)

Sebagai sahabat bromance, Miko juga memberi nasihat dan pertimbangan rasional saat diminta. Ia tahu bahwa Rian sangat menyukai Rara, tapi ia tidak ingin jika Rian berharap terlalu banyak karena tidak lama lagi akan pergi. Situasi ini mengafirmasi gagasan Aiken (Febrieta, 2016), bahwa hubungan persahabatan menyediakan dukungan emosi serta informasi yang dapat meningkatkan kualitas hidup.
" $\mathrm{Ck}$, lo gimana sih? Kan gue udah bilang minta maaf dulu. Kalo perlu, lo pake ngaku salah. Baru habis itu lo ajak dia makan bareng ntar siang."

"Iya itu, Mik. Gue lupa tadi." [...]

"Nggak ngubah keadaan, kan? Sama aja buat elo?" tanya Miko setelah sempat beberapa detik terdiam.

"Iya." Rian mengangguk.

"Ya udah. Relain aja kalo gitu." (Kinasih, 2020: 181)

Laki-laki dalam relasi bromance juga akan membantu kelancaran temannya dalam mencapai suatu target tertentu. Miko sepanjang cerita ditampilkan secara aktif menolong Rian berkali-kali, mulai dari mencarikan info tentang Rara hingga membantu menghalangi acara makan Roni dan Rara.

Miko nyeritain hasil kasakkusuknya berdua Rian selama jam fisika tadi. Garis besarnya aja, biar cepat.

"Serius?" Irwan tertawa. "Ayo! Apa aja deh yang bisa bikin tuh anak seneng, gue bantuin." (Kinasih, 2020: 183-184)

Relasi rival pun dapat berubah mengarah menjadi bromance seperti yang dialami Rian dan Roni saat mereka secara tidak sengaja terlibat tawuran dengan siswa dari sekolah lain. Mau tidak mau, karena berasal dari satu almamater maka keduanya harus saling melindungi. Namun, sejak saat itu, pandangan Roni yang buruk tentang Rian berubah.

"Kalo lo mau mukul, pukul gue. Jangan adik gue!" Ria ngomong dengan tegas ke pentolan STM 
Dirgantara. Roni jelas kaget, mendadak diakuin jadi adik oleh Rian. (Kinasih, 2020: 246)

Pengakuan bohong Rian bahwa Roni adalah adiknya merupakan bentuk perlindungan. Pernyataan tersebut mengubah cara pandang Roni pada Rian menjadi jauh lebih baik. Mereka pun merasa menjadi dekat dan memahami satu sama lain. Sahabat pun dapat pula berperan sebagai rival yang membantu laki-laki melakukan introspeksi diri, sebagaimana terjadi pada Roni. Meskipun sempat ada persaingan tidak sehat di antara mereka, namun pada akhirnya, permasalahan diselesaikan dengan kepergian Rian ke Sulawesi.

Rian mengulurkan tangan kanannya. Dia merangkul Roni. Dia udah nggak bisa ngomong apaapa lagi. Dia udah di ujung waktu. Roni membalas rangkulan Rian. Dia bisa merasakan rangkulan itu menguat. Roni paham. Waktu mereka selesai. Rian harus pergi.

"Baik-baik lo di tempat baru ya." Suara Roni terdengar serak. (Kinasih, 2020: 277)

Pada kutipan tersebut terlihat bahwa bromance pun dapat membuat laki-laki menjadi emosional karena empati yang mendalam terhadap perasaan temannya. Dalam hal ini, Roni turut merasa sedih saat melihat Rian yang juga merasa berat harus pergi.

Dari pembahasan dan kutipankutipan tersebut, diketahui bahwa relasi bromance dibangun di antara para tokoh laki-laki dalam latar sekolah dan konteks permasalahan remaja. Alasan yang mendasari bromance terutama adalah karena adanya kesamaan kepentingan dan pemahaman sebagai sesama laki-laki. Manifestasi bromance ditunjukkan dalam novel Untuk Dia melalui sikap laki-laki yang mau mendengarkan, mau memahami, membantu, dan melindungi sahabatnya.

\section{Kompleksitas Bromance dan Maskulinitas}

Dalam relasi bromance, menurut Imelda (2017), laki-laki dapat menjadi sangat transparan dalam bersikap. Seorang laki-laki misalnya dapat mengakui bahwa ia menyukai lagulagu Taylor Swift (yang sangat feminin) pada sahabat laki-lakinya, daripada terbuka terhadap kekasihnya yang perempuan. Laki-laki itu bisa saja diragukan maskulinitasnya dan dikucilkan jika bila melakukan pengakuan seperti itu.

Kajian gender mengidentifikasi perbedaan laki-laki dan perempuan dari segi sosial budaya. Laki-laki, misalnya, selalu diasumsikan sebagai sosok yang kuat, gagah, dan pemberani. Laki-laki kerap diidentikkan dengan perilaku kekerasan. Siswa SMA yang tidak bisa/mau berkelahi akan dinilai 'seperti perempuan'. Hal ini sejalan dengan pandangan Tong (2010) bahwa ideologi gender menyebabkan ekspektasi terhadap gender tertentu. Seorang laki-laki yang berperilaku tidak sesuai dengan citra maskulin akan dialienasi.

Dalam konteks siswa SMA di Jakarta, perilaku kekerasan yang dilakukan secara bersama-sama mewujud pada bentuk 'tawuran' melawan sekolah lain, atau mengganggu seorang waria di jalan sebagai hiburan.

Kenyang makan gultik, yang dilahap sambil ngobrol dengan riuh dan ketawa-tawa, Rian dan teman-temannya jadi merasa 
punya energi buat ngundang masalah. Mereka kemudian berkeliaran di Blok M, nyari-nyari ikon Blok M yang cukup kesohor dalam menebarkan teror. Mariam Blok M. (Kinasih, 2020: 239)

Dengan alasan iseng, dalam kutipan tersebut terungkap bagaimana Rian dan teman-temannya menggoda seorang waria Blok $\mathrm{M}$ terkenal di tahun 80-90-an yang dipanggil dengan nama Mariam. Situasi ini menunjukkan bahwa keberanian untuk melakukan tindakan yang tidak biasa dapat diperoleh dari situasi kolektif. Meskipun laki-laki distereotipkan memiliki sifat pemberani, mereka tentunya tidak akan mau dan mampu melakukan tindakan tersebut jika sedang sendiri. Laki-laki memang merasa nyaman saat bersama dengan teman-temannya. Dengan berada berkelompok, mereka merasa superior dan memegang kendali.

Meskipun laki-laki dikonstruksi sebagai sosok yang gemar berkompetisi dan berkelahi, namun laki-laki juga bersifat rasional. Mereka tidak mau kalah secara konyol bila telah tahu tidak akan dapat memenangkan peperangan.

Istirahat kedua Roni udah niat mau ke gedung tempat kelas-kelas tiga, tapi dilarang teman-teman cowok.

"Kalo lo ke sana, lo cuma bikin masalah tambah runyam. Ntar lo malah diapa-apain di sana," kata Riyaldi. "Apalagi gue kan paling nggak bisa kalo tau ada temen sekelas yang diapa-apain anak kelas tiga." (Kinasih, 2020: 116)

Pembiasaan dan normalisasi terhadap kultur kekerasan berupa perkelahian dan 'tawuran' antarsekolah telah dianggap sebagai kenakalan remaj biasa. Hal ini dipandang Bekowitz yang dikutip Oesman (2010) berkaitan dengan pola perilaku agresif, baik secara fisik maupun simbolis, yang dilakukan dengan tujuan menyakiti orang lain. Dalam konteks sosial, kekerasan yang dilakukan laki-laki dianggap sebagai konsekuensi dari maskulinitas yang tidak membatasi ruang geraknya, yang kemudian membedakannya dengan femininitas (Nodelman, 2002).

Selain berkaitan dengan toleransi pada nilai kekerasan sebagai akibat kerangka kerja patriarkis, kekompakan laki-laki dalam relasi bromance juga dapat berupa tindakan-tindakan aneh dan usil. Dalam novel Untuk Dia terungkap adanya permainan "Sekilas pantat" yang dilakukan para siswa lakilaki ssebagai bentuk hiburan setelah ulangan/ ujian.

\section{"SEKILAS PANTAAAT!"}

Disusul suara-suara gaduh yang sengaja mereka buat. Ada yang tepuk tangan. Ada yang mukulmukul meja. Ada yang suit-suit. Yang berseru "Sekilas Pantaaat!" nggak semua sih. Kebanyakan cowok-cowok. Cewek cuma sebagian. Yang sebagian lagi cuma tertawa-tawa, malu ngikutan seruan kalimat itu. (Kinasih, 2020: 126)

Kesukaan para siswa laki-laki dalam berbagi kesenangan juga ditunjukkan oleh Riyaldi dan Toto yang mendengarkan lagu-lagu cadas heavy metal melalui walkman bersama-sama dengan earphone (hlm. 173). Demikian pula dengan penyewaan stensilan oleh Riyaldi khusus untuk teman-temannya yang laki-laki. Mereka tidak segan untuk menjahili teman-temannya 
dengan mengambil makanan atau menyembunyikan alat tulis sebagai bentuk candaan keakraban.

Acara makan batagornya seru banget. Cowok-cowok itu makan sambil ngobrol. Ngomongin segala macam. Ketawa cekakakan. Toyor-toyoran. Saling ngembat isi piring teman begitu yang pegang piring sedikit meleng. (Kinasih, 2020: 209)

Bukan hanya Roni dan temanteman sekelasnya yang menjalin persahabatan, tapi juga Rian dengan teman-temannya. Hal tersebut misalnya terlihat saat mereka secara kompak turut merayakan ulang tahun Rara demi membantu pendekatan yang dilakukan Rian. Manifestasi bromance dalam konteks ini merupakan pelanggaran atas maskulinitas yang menetapkan laki-laki sebagai sosok yang mandiri dan mampu menyelesaikan masalahnya sendiri.

Teman-teman Rian yang duduk di lapangan voli kini berdiri. Rara mengira cowok-cowok itu mau pulang. Dia mau bilang terima kasih sebelum mereka semua pergi. Tapi mereka justru menghampiri Rara. Cowok pertama yang sampai di depan Rara mengulurkan tangan sambil membungkukkan badan.

"Met ulang tahun ya, Ra," katanya sambil tersenyum. (Kinasih, 2020: 208)

Kekompakan Rian atau Roni dengan teman-temannya ditampilkan melalui perilaku kolektif yang cukup kerap ditampilkan dalam novel Untuk Dia, seperti duduk berdesak-desakan di dalam mobil. Remaja laki-laki juga terbiasa bersama-sama berganti pakaian di ruang kelas sebelum pelajaran olahraga, sementara para siswi terusir berganti pakaian di toilet yang jauh letaknya.

Laki-laki dalam kelompok juga ditampilkan solid dalam kegiatan fisik yang membutuhkan kerjasama tim, sebagaimana digambarkan saat mereka bermain basket sementara teman-teman perempuan menonton.

Rian menahan langkah temantemannya. Dengan punggung membelakangi lapangan, Rian ngomong sesuatu ke temantemannya. Feeling Rara langsung nggak enak. Soalnya temanteman Rian sebentar-sebentar ngelihat ke lapangan basket, tempat cowok-cowok 2 Fis 2 yang nggak balik ke kelas sedang melanjutkan permainan mereka. (Kinasih, 2020: 110)

Sementara laki-laki berkembang dan bekerja sama, perempuan dalam novel Untuk Dia justru ditampilkan lemah, pasif, dan tersubordinasi. Rara misalnya, digambarkan menangis saat mengetahui Rian akan pergi meninggalkannya. Ia menyukai sosok Rian yang sering mengganggu dan membentaknya itu. Mental yang labil juga ditampakkan perempuan itu saat ia dengan mudah kembali menyukai Roni karena laki-laki itu mencurikan mangga untuknya.

Dari analisis ini, diketahui bahwa bromance tidak hanya dibangun atas sikap pengertian dan solidaritas sebagai sesama laki-laki, tapi juga karena keinginan untuk menghibur diri. Relasi bromance menguat karena laki-laki bersatu untuk tidak ingin tampil sebagai pihak yang lemah dan emosional di hadapan perempuan. Tokoh perempuan 
dalam novel Untuk Dia sendiri ditampilkan pasif, menunggu, lemah, dan tidak berdaya menghadapi laki-laki dan kekuatan bromance mereka.

\section{PENUTUP}

Hasil penelitian ini menunjukkan bahwa relasi bromance dalam novel Untuk Dia dibangun di antara para tokoh laki-laki dengan latar sekolah dan konteks permasalahan remaja. Bromance terbentuk karena adanya kesamaan kepentingan dan pemahaman sebagai sesama laki-laki. Manifestasi bromance ditunjukkan melalui sikap mendengarkan, memahami, membantu, dan melindungi.

Relasi bromance menguat karena laki-laki bekerja sama untuk tidak tampil sebagai pihak yang lemah dan emosional (terutama) di hadapan perempuan. Sementara itu, perempuan ditampilkan pasif, lemah, dan patuh menghadapi kekuatan laki-laki dan persekutuan mereka dalam bromance.

Dengan demikian, dapat dinyatakan bahwa hasil kajian ini menyepakati penelitian-penelitian terdahulu tentang bromance, bahwa laki-laki merasa nyaman saat bersama dengan teman-temannya. Sesuai dengan kajian Putri, Hamad, dan Rusadi (2018), bromance di dalam novel Untuk Dia juga menunjukkan adanya sifat fluid gender pada laki-laki.

\section{DAFTAR PUSTAKA}

Adji, M. (2017). Budaya Anak Muda pada Sastra Populer (D. Suganda Ed.). Bandung: Unpad Press.

Agnes, T. (2016). Esti Kinasih Kembali dengan Novel Teen lit Jingga Untuk Matahari. DetikHOT. https://hot.detik.com/book/337335 8/esti-kinasih-kembali-dengan- novel-teenlit-jingga-untukmatahari

Anwar, F. (2017). Bromance, Ketika Pria 'Terikat' Pertemanan. Detikhealth. https://health.detik.com/beritadetikhealth/d-3498740/bromanceketika-pria-terikat-pertemanan-erat

Beauvoir, S. d. (2016). Second Sex: Fakta dan Mitos. Jakarta: PT. Buku Seru.

Brook, H. (2015). Bros before Ho(mo)s: Hollywood Bromance and the Limits of Heterodoxy. Men and Masculinities, 18(2), 249-266.

Cavanaugh, J. C. d. B.-F., F. (2006). Adult development and aging (5th ed.). Belmont: Thomson Learning.

Connell, R. (2005). Masculinities (2e ed.). Berkeley - Los Angeles: University of California Press.

Davies, K. d. A., A. (2016). Friendship development and intergroup friendship processes. Journal of Social Issues, 72(3), 489-510.

Faruk. (2012). Sastra sebagai Produk dan Produsen Kebudayaan Sebuah (De)Konstruksi. Yogyakarta: Yasayo.

Febrieta, D. (2016). Relasi Persahabatan. Jurnal Kajian Ilmiah UBJ, 16(2), 152-158.

Hanani, S. U. R., Nilla. (2019). Representasi Bromance dalam Film Indonesia Berlatar Belakang Budaya Jawa Yowis Ben. MetaKom, 3(2), 51-63.

Imelda. (2017). Bagi Pria, Bromance ternyata Lebih Penting daripada Hubungan Asmara. Womantalk. 
https://womantalk.com/friendship/ articles/bagi-pria-bromanceternyata-lebih-penting-daripadahubungan-asmara-xqzOQ.

Intan, T. (2019). Cinderella Complex pada Teen Lit Eiffel I'm in Love karya Rahmania Arunita dan Fairish karya Esti Kinasih. Jentera: Jurnal Kajian Sastra, 8(2), 168. doi:http://dx.doi.org/10.26499/jent era.v8i2.1476

Jumail, Z. S., Amirudin Rahim. (2019). Pendidikan Karakter dalam Novel Jingga dan Senja Karya Esti Kinasih, Analisis Kelayakan Sebagai Bahan Ajar Sastra di SMA/MA. Jurnal Pendidikan Bahasa, 1(8), 32-43.

Kinasih, E. (2004). Fairish. Jakarta: Gramedia Pustaka Utama.

Kinasih, E. (2010). Jingga dan Senja. Jakarta: Gramedia Pustaka Utama.

Kinasih, E. (2020). Untuk Dia Yang Terlambat Gue Temukan. Jakarta: PT Gramedia Pustaka Utama.

Kirnandita, P. (2017). Bromance: Mesra tanpa Asmara. Tirto.id. https://tirto.id/bromance-mesratanpa-asmara-cy 79

Kriswanti, W. (2019). Bromance, Memahami Kebutuhan Pria akan Teman Pria. LineToday. https://today.line.me/id/v2/article/7 RLPV8

Kurniawan, W. P., Andriani, V., Rikayama, T. (2020). Pembuatan Film Pendek Bertemakan Persahabatan "How Bromance Us". JTIM: Jurnal Teknologi Informasi dan Multimedia, 2(2), 109-115.
Maharrani, A. (2017). Bromance lebih memuaskan bagi sebagian laki-laki.

Berita Tagar.

https://beritagar.id/artikel/gaya-

hidup/bromance-lebih-

memuaskan-bagi-sebagian-laki-

$\underline{\text { laki }}$

Nodelman, P. (2002). Making Boys Appear: the Masculinity of Children's Fiction. In J. Stephens (Ed.), Ways of Being Male. New York: Routledge.

Noor, R. (2017). Sastra Populer dan Masalah Mutu Penelitian Sastra di Perguruan Tinggi. Nusa, 12(4), 265-275.

Oesman, A. T. (2010). Fenomena Tawuran sebagai Bentuk Agresivitas Remaja (Kasus Dua SMUN di Kawasan Jakarta Selatan). (Skripsi), Institut Pertanian Bogor, Bogor.

Oh, D. C. (2018). Elder men's bromance in Asian lands: normative Western masculinity in Better Late than Never. Critical Studies in Media Communication. doi:10.1080/15295036.2018.14631 02

Pachrunisyah, I., Charlina, Rumadi, H. (2017). Masculinity Female Characters in A Novel Cewek!!! by Esti Kinasih Jurnal Online Mahasiswa FKIP, 4(1), 1-8.

Permata, D., Priyatna, A., Rahayu, L.M. (2016). Dinamika Maskulinitas dan Femininitas dalam Novel Seperti Dendam, Rindu Harus Dibayar Tuntas Karya Eka Kurniawan. Metasastra, 9(1), 13-24. 
Priyatna, A. (2018). Kajian Budaya Feminis Tubuh, Sastra, dan Budaya Pop. Yogyakarta: Arti Bumi Intaran.

Putri, S. S., Hamad, I., Rusadi, U. (2018). Bromance Representation in Popular Korean Drama: A Korean Odyssey Drama in Online Video Streaming Sites. Paper presented at the Indonesia International Graduate Conference on Communication, .

Putri, W., Mursalim, Dahri Dahlan. (2020). Tanggapan Remaja di Samarinda terhadap Novel Populer Jingga dan Senja Karya Esti Kinasih: Kajian Resepsi Sastra. Ilmu Budaya: Jurnal Bahasa, Sastra, Seni, dan Budaya, 4(2), 201-210.

Rahmaningsih, N. D. M., W. . (2014). Dinamika Konsep Diri Pada Remaja Perempuan Pembaca Teenlit. Jurnal Psikologi Indonesia, 41(2), 179 - 189

Rinesti, K. L. (2016). Bromance, Kenapa Nggak? . PijarPsikologi. https://pijarpsikologi.org/bromance -kenapa-nggak/

Robinson, S. A., Eric; White, Adam. (2017a). The Bromance: Undergraduate Male Friendships and the Expansion of Contemporary Homosocial Boundaries. Sex Roles. doi:http://dx.doi.org/10.1007/s111 99-017-0768-5

Robinson, S. W., Adam; Anderson, Eric. (2017b). Privileging the
Bromance: A Critical Appraisal of Romantic and Bromantic Relationships. Men and Masculinities, 1-22. doi:https://doi.org/10.1177/109718 $\underline{\text { 4X17730386 }}$

Setiaji, B. R. (2020). Bromance (Persahabatan Laki-laki) Tak Kalah Solid dengan Persahabatan Perempuan. HelloSehat. https://hellosehat.com/mental/hubu ngan-harmonis/apa-itu-bromanceadalah/

Tait, R. C. (2016). The Screwball Bromance: Regression, Bisexuality, and Reconfigured Masculinity in Step Brothers. Journal of Men's Studies, 24(1), 60-77.

Thomson, L. J. (2015). Reading the bromance: homosocial relationships in film and television. Journal of Gender Studies, 24(3), 368-370.

doi:http://dx.doi.org/10.1080/0958 $\underline{9236.2015 .1005976}$

Tong, R. P. (2010). Feminist Thought: Pengantar Paling Komprehensif Kepada Aliran Utama Pemikiran Feminis (A. Priyatna, Trans.). Yogyakarta: Jalasutra.

Widjayanti, E. P. (2016). The Ideology of Popular Culture in Esti Kinasih's Fairish. Leksema, 1(2), 99-109.

Wolfe, K. (2016). 5 Reasons Guys Need Bromance. goodguyswag. http://goodguyswag.com/reasonsguys-need-bromance/ 